\title{
The Relationship Between Complementary Feeding and Stunting Eventsin 2 to 5 Years of Age
}

\section{Sefrina Rukmawati, Puji Astutik, Puji Rahayu Slamet}

High School of Health Sciences of Satria Bhakti, Nganjuk

Email:

sefrinarkmawati99@gmail.com
Received : October 5, 2020

Accepted : November 22, 2020

Published : November 30, 2020
Background: Lack of complementary feeding for children, from the age of 6 months complementary feeding begins to be necessary. Food that not good enough in both quality and quantity would affect stunted growth.

Purpose: This research was to determine the relationship of complementary feeding with the stunting in 2 to 5 years of age

Method: This research is a retrospective approach. This research is carrying on March 4 2020. The population of this research is one of the parents and children aged 2-5 years as many as 22 people. Sampling retrieval using total sampling, totaling 22 parents and children. The independent variable of complementary feeding data collection with the questionnaire and the dependent variable stunting event data collection by the child's height measurement. Data analysis using spearman rank with $\alpha=0.05$.

Results show that out of 22 respondents, nearly half of which were 10 respondents $(45.5 \%)$ provide less complementary feeding in the category of less and children aged 2-5 years the majority of 16 respondents $(72.7 \%)$ having heights in the short category. Correlation test results show $\mathrm{p}$-value $=0.002 \alpha=0.05$, so Ha is accepted.

Conclusion: There is a relationship between complementary feeding with stunting in children aged 2-5 years, and $\mathrm{r}=0.627$ so the level of closeness is strong. In this research the becomes a strong predictor in caused the stunting, but was expected to further research can add various other variables to the stunting event.

Keywords: Complementary food, stunting, toddler

Copyright (C) 2020 IIK STRADA Indonesia All right reserved.

This is an open-acces article distributed under the terms of the Creative Commons Attribution-ShareAlike 4.0 International License.

\section{INTRODUCTION}

Stunting or short is a condition of failure to thrive in infants (0-11 months) and children under five (12-59 months) as a result of chronic malnutrition, especially in the first 1000 days of life so that the child is too short for his age (PERSAGI, 2018). The incidence of stunting at the age of five will cause a decline in intellectual abilities and growth. Growth disorders can begin after the child is 6 months old because from then on, complementary foods with breast milk are needed to meet nutritional needs. Food that is not sufficient both in quality and quantity will have an impact on underdeveloped growth (Adisasmito, 2009). Based on a preliminary study in the form of interviews with mothers who have stunted children under five and observations by researchers by door to door to 
the house of mothers who have stunting children, there are 16 children who are stunted. This happens because mothers are not given appropriate complementary feeding both in terms of the time for the first time and in terms of quality and quantity. Of the 16 stunting children under five $(37.5 \%)$ who received complementary foods less than 6 months old, 1 toddler $(6.25 \%)$ received complementary foods older than 12 months, 4 (25\%) children under five received complementary foods of breast milk more than 7 months and 5 toddlers $(31.25 \%)$ get complementary foods of breast milk at exactly 6 months. However, from the 16 toddlers, when viewed in terms of quality and quantity of complementary foods given, it is still lacking. Because mothers provide more of one type of food that the child likes and the average stunted toddler has less appetite because the mother is less creative in varying the food to attract the child's attention. This is what makes children's nutritional needs insufficient.

Based on stunting prevalence data collected by the World Health Organization (WHO), Indonesia is the third country with the highest prevalence in the Southeast Asia / South-East Asia Regional (SEAR) region. The average prevalence of stunting under five in Indonesia in 2005-2017 is $36.4 \%$. Meanwhile, the prevalence of stunting in Indonesia has reached $30.8 \%$. However, based on WHO standards, this figure is still very high because the target of reducing the stunting rate is less than 20\%. In the Nganjuk area, the prevalence of stunting in 2018 was 16.1\% and is the 9th in East Java. Ngluyu Subdistrict is ranked first in Nganjuk Regency with the highest stunting rate, namely $21.3 \%$ (122 toddlers) (Dinkes, 2019). Many factors influence the occurrence of stunting in children aged 2-5 years, the causes ranging from women of childbearing age with LILA $<23 \mathrm{~cm}$, maternal energy sufficiency, anemia in pregnant women, maternal height, low birth weight, toddler health services, family economic status, total household members, education, sanitary conditions and access to drinking water, infection factors, provision of complementary and exclusive breastfeeding. Complementary feeding is a major problem that is a contributing factor to stunting. If complementary foods are not given to children aged 6-12 months, there will be nutritional or nutritional deficiencies in the baby because complementary feeding which is more dominant affects the energy and nutritional adequacy of children aged 6-12 months compared to low consumption of complementary foods which are factors that cause low intake of energy and nutrients and cause stunting (Rosadi, Rahayuh, Yulidasari, \& Octaviana, 2016).

Complementary foods of breast milk is a process of transition from solely milk-based intake to semi-solid foods. The introduction and provision of complementary foods should be carried out gradually in both form and quantity, according to the digestive capacity of the baby / child (Bennu, et al. 2012). It is hoped that the provision of complementary complementary foods can not only meet the nutritional needs of infants, but also stimulate feeding skills and stimulate self-confidence in infants (Depkes, 2009).

Therefore, to prevent stunting, it is necessary to provide adequate complementary breastfeeding, both in terms of time, quality and quantity for physical growth and the development of children's intelligence which is increasing rapidly in this period. As the baby grows older, his nutritional needs increase, so he must increase the milk dose so that the baby gets energy for growth and development. Breast milk only meets the nutritional needs of infants as much as $60 \%$ of infants aged 6-12 months. The rest must be fulfilled with other foods that are sufficient in quantity and good nutrition (Benne, 2012). Therefore, at the age of 6 months and above, babies need additional other nutrients from complementary foods, but the complementary foods given must also be of high quality (Mufida, 2015).

\section{OBJECTIVE}

Objective states the major of the study Knowing the relationship of complementary feeding (MP-ASI) with the incidence of stunting in children aged 2-5 years.

\section{METHOD}

This research is a retrospective approach. The population of this research is one of the parents and children aged 2-5 years as many as 22 people. Sampling retrieval using total sampling, totaling 22 parents and children. The independent variable of complementary feeding data collection with the questionnaire and the dependent variable stunting event data collection by the child's height measurement. Data analysis using spearman rank with $\alpha=0.05$ 


\section{RESULTS}

a. History of complementary feeding for children aged 2-5 years

Based on table 1 it can be seen that of the 22 respondents, almost half, namely 10 respondents $(45.5 \%)$ gave less complementary foods to their children.

Table 1 Frequency Distribution History of complementary feeding for children aged 2-5 years

\begin{tabular}{ccc}
\hline Complementary Feeding & Frequency $(f)$ & Percentage (\%) \\
\hline Well & 4 & 18.2 \\
Enough & 8 & 36.4 \\
Less & 10 & 45.5 \\
Total & 22 & 100 \\
\hline
\end{tabular}

b. Incidence of stunting in children aged 2-5 years

Table 2 Frequency Distribution of Stunting in Toddlers Age 2-5 Years

\begin{tabular}{ccc}
\hline Stunting & Frequency $(f)$ & Percentage $(\%)$ \\
\hline Very short & 6 & 27.3 \\
Short & 16 & 72.7 \\
Total & 22 & 100 \\
\hline
\end{tabular}

Based on table 2, it can be seen that of the 22 respondents, most of them 16 respondents $(72.7 \%)$ have a short height that does not match their age.

\section{c. The relationship of complementary feeding with the incidence of stunting in children aged 2-5 years}

Table 3 The relationship of complementary feeding with the incidence of stunting in children aged 2-5 years

\begin{tabular}{ccccccc}
\hline Complementary & \multicolumn{4}{c}{ Stunting } & \multicolumn{2}{c}{ Total } \\
Feeding & \multicolumn{2}{c}{ Short } & \multicolumn{2}{c}{ Very Short } & \multicolumn{1}{c}{$\%$} \\
& $f$ & $\%$ & $f$ & $\%$ & $\sum$ & $\%$ \\
\hline Well & 4 & 18.2 & 0 & 0 & 4 & 18.2 \\
Enough & 8 & 36.4 & 0 & 0 & 8 & 36.4 \\
Less & 4 & 18.2 & 6 & 27.3 & 10 & 45.5 \\
Total & 16 & 72.7 & 6 & 27.3 & 22 & 100 \\
\multicolumn{2}{r}{ Spearman Rank, $P$ value $=0,002 \alpha=0,05 r=0,627$} \\
\hline
\end{tabular}

Based on table 3 it is known that of the 22 respondents, almost half, namely 8 respondents (36.4\%) indicated that complementary feeding was in the sufficient category and the height of children aged 2-5 years was in the short category.

The result of the spearman rank correlation test shows p-value $=0.002 \leq(0.05)$, so that Ha is accepted or Ho is rejected, meaning that there is a relationship between complementary feeding with the incidence of stunting in children aged 2-5 years. The correlation coefficient value (r) of 0.627 indicates the closeness of the strong relationship and the direction of the positive relationship, meaning that the better complementary feeding is suitable for toddlers aged 2-5 years, and vice versa. 


\section{CONCLUSION}

\section{a. Complementary feeding (MP-ASI) for stunting toddlers aged 2-5 years}

The results of this study indicate that of the 22, almost half of them in giving complementary foods to breastfeeding are lacking in children aged 2-5 years, as many as 10 respondents $(45.5 \%)$. If it is related to general data, it is known that the aspect that has a significant relationship with complementary feeding is maternal education ( $p$-value $=0.024$ ). It can be seen that mothers who provide complementary foods in the less category have an average education that ends at the junior high school level.

According to (Septiana, 2010) maternal education is one of the factors that influence complementary feeding (complementary feeding). education is an activity or learning process that occurs anywhere, anytime and by anyone. A person can be said to learn when in him there is a change from not knowing to knowing, from not doing to doing something. Education can affect a person's level of knowledge, the higher the level of education of a person, the easier it is to receive information, so the better the knowledge. Low levels of education will find it difficult to digest the messages or information conveyed (Notoadmojo, 2010). (Wirdayanti, 2019) stated that the mother's lack of knowledge about proper complementary feeding causes the child not to get maximum nutritional intake so that the child has a malnutrition status and even becomes stunted. Providing appropriate and good complementary foods so that children's nutritional needs are met so that growth failure does not occur. The complementary foods that are given must also be varied, given gradually from the form of being crushed, soft until they become accustomed to family food. The results of other studies show that babies who are stunted are mostly not getting the right complementary foods. (Suhardjo, 2000) states that this is related to the higher the level of education of the mother, the easier it is for her to absorb nutrition and health information, so that the knowledge and parenting patterns of mothers in providing complementary foods will be better.

In this study, it was stated that almost half of them, namely 10 respondents $(45.5 \%)$ of mothers, gave less complementary foods to children. This is because the mother is impatient or trained in providing complementary foods to children. Because based on the facts in the field, the average child has no appetite, does not like vegetables, and only likes one type of food. Then the mother every day only gives the type of food that the child likes. This has resulted in insufficient nutritional needs for children. Even though every activity has been given counseling about the importance of giving complementary foods and often held competitions for the contents of my plate, the purpose of this competition is to find out how mothers provide food to children, whether it is appropriate between, age, portion, texture and type of food given. However, this is only done at the posyandu, not at home.

Actually, mothers with junior high school education are considered to have sufficient insight into giving complementary foods to children and are able to think rationally and open themselves to information and sources that can be accounted for. So it can be concluded that the mother's patience and patience in giving complementary foods to children is very important because complementary feeding is a transition period from solely milk-based intake to semi-solid foods. The introduction and provision of complementary foods should be carried out gradually in both form and quantity, according to the digestive capacity of the baby / child. The provision of appropriate complementary foods not only meets the nutritional needs of infants, but also stimulates feeding skills and stimulates children's self-confidence.

\section{b. Incidence of Stunting in Toddlers Ages 2-5 Years}

Based on the research results in table 4.3, it can be seen that the incidence of stunting, all respondents, namely 22 respondents $(100 \%)$, experienced stunting. Almost all respondents with short height category are 16 respondents $(72.7 \%)$ and almost half of them are 6 respondents (27.3\%) with very short height category. Apart from that, from the demographic data of the respondents, which includes maternal age, occupation of mothers, maternal education, age of children under five, gender, and history of childbirth, none of these affect the incidence of stunting in children aged 2-5 years. This can be seen from the results of the frequency tabulation that almost all 19 respondents $(86.4 \%)$ have jobs as housewives, almost part of which is 10 
respondents $(45.5 \%)$ have junior high school education, mostly 13 respondents $(59,1 \%)$ toddlers aged 2-2.9 years, and almost all 21 respondents $(95.5 \%)$ had a history of normal childbirth.

This is not in accordance with the theory put forward by Anisa (2012) quoted by Aridiyah (Aridiyah, 2015), which states that the incidence of stunting in children under five has a relationship with the level of education of mothers, both in rural and urban areas. The above opinion is supported, which states that the level of maternal knowledge about nutrition is one of the factors that can affect the incidence of stunting in children under five. Knowledge about nutrition is the initial process in changing the behavior of increasing nutritional status, so that knowledge is an internal factor that influences changes in behavior, knowledge of mothers about nutrition will determine the behavior of mothers in providing food for their children. Mothers with good nutritional knowledge can provide the right type and quantity of food to support the growth and development of children under five (Aridiyah, 2015). This contradicts the results of the study (Candra, 2015) which states that there is no significant relationship between maternal education level and the incidence of stunting. The level of education of the mother does not guarantee that the child will avoid malnutrition because a high level of education does not mean that the mother has sufficient knowledge of good nutrition. In addition, higher education levels do not guarantee sufficient economic status. Mothers who have a high level of education are more likely to work as career women than as housewives so that child care is left to caregivers who do not necessarily have sufficient education and knowledge. This is probably the reason why the low level of maternal education is not a risk factor for stunting in children.

Whereas mothers with junior high school education are considered to have sufficient insight into giving complementary foods to children and are able to think rationally and open themselves to information and sources that can be accounted for. Knowledge about nutrition is not only obtained from formal education but also through non-formal education, such as personal experience, media, environment, and health education. If the mother's knowledge is good about nutrition, the nutritional needs of the child will be fulfilled.

\section{c. Relationship of Complementary Feeding with the incidence of stunting in children aged 2-5 years.}

The results of this study indicate that of the 22 parent respondents, almost half of them showed complementary feeding in the deficient category, namely 10 respondents $(45.5 \%)$ and the incidence of stunting in aged children. 2-5 short years, as many as 16 respondents $(72.7 \%)$ and 6 respondents $(27.3 \%)$ in the very short category. The result of the spearman rank correlation shows a p-value of 0.002 , so that $\mathrm{Ha}$ is accepted or Ho is rejected, meaning that there is a relationship between complementary feeding and the incidence of stunting in children aged 2-5 years at Posyandu, Gampeng Village, Ngluyu District, Nganjuk Regency. The correlation coefficient ( $r$ ) of 0.627 shows the closeness of a strong relationship and towards a positive relationship, meaning that the better the provision of complementary feeding, the more appropriate the growth and development of children aged 2-5 years, and vice versa.

(Mufida, 2015) Stating that complementary foods to breastfeed (MP-ASI) are given from the age of 6 months. The purpose of giving complementary foods is to provide adequate nutrition for the needs of babies or toddlers for optimal physical and psychomotor growth, in addition to educating babies to have good eating habits. This goal can be achieved well if the provision of complementary foods according to age, quality and quantity of food is good as well as various types of food.

Nearly half, namely 10 mothers (45.5\%) children aged 2-5 years, providing complementary foods to underweight children. This happens because of the lack of patience or lack of training in giving complementary foods to children so that the nutritional needs of the child are not fulfilled resulting in the child not growing optimally according to his age. In fact, as they get older, the nutritional needs of children to carry out the process of growth and development also increase.

At 6-12 months of age, breast milk provides only $1 / 2$ or more of the nutritional needs of the baby, at 12-23 months of breastfeeding only provides $1 / 3$ or more of the nutritional needs. Therefore, we need complementary foods to increase energy and nutrients needed for the process of growth and development since the baby starts at 6 months of age. However, complementary 
foods must also contain micronutrients which begin to decrease in breast milk so that it will be sufficient for the baby's nutrition not only from breast milk. Appropriate complementary feeding has an impact on optimal growth and development, prevents malnutrition, avoids nutritional deficiencies, and prevents micronutrient deficiencies.

\section{ACKNOELEDGEMENT}

I say thank you to the respondents who are willing to be respondents in this study.

\section{CONFLICTS OF INTEREST}

There are no conflict in this study.

\section{REFERENCE}

Adisasmito. (2009). Sistem Kesehatan . Jakarta: PT Raja Grafindo.

Aridiyah. (2015). Faktor-Faktor Yang Mempengaruhi Kejadian Stunting Pada Anak Balita Di Wilayah Pedesaan Dan Perkotaan. Pustaka Kesehatan, -.

Benne, D. (2012). Hubungan Pemberian Makanan Pendamping ASI (MP-ASI) Dengan Status Gizi Bayi Usia 6-12 Bulan Di Posyandu Kurusumange Kecamatan Tanralili Kabupaten Maros. Poltekes Kemenkes Makasar, 1 \& 4.

Candra, A. (2015). Hubungan Underlying Factors Dengan Kejadian Stunting. Fakultas Kedokteran Universitas Diponegoro.

Depkes. (2009). Pedoman Umum Pemberian Makanan Pendamping Air Susu Ibu (MP-ASI) Lokal. Jakarta: Departemen Kesehatan Republik Indonesia.

Dinkes. (2019). Angka Prevalensi Stunting Tertinggi di kabupaten Nganjuk. Kabupaten Nganjuk: Dinas Kesehatan.

Mufida, d. (2015). Prinsip Dasar Makanan Pendamping Air Susu Ibu (MP-ASI) Untuk Bayi 6-24 Bulan. FTP Universitas Brawijaya.

Notoadmojo. (2010). Ilmu Kesehatan Masyarakat. Jakarta: Rineka Cipta.

PERSAGI. (2018). Stop Stunting Dengan Konseling Gizi. Penebar Plus.

Rosadi, D., Rahayuh, A., Yulidasari, F., \& Octaviana, A. (2016). Faktor Resiko yang Berhubungan Dengan Kejadian Pendek pada Anak Usia 6 - 24 Bulan. Kesehatan Masyarakat, 11.

Septiana, R. (2010). Hubungan Antara Pola Pemberian Makanan Pendamping ASI (MP-ASI) dan Status Gizi Balita Usia 6-24 Bulan Diwilayah Kerja Puskesmas Gedongtengen Yogyakarta. Universitas AHmad Dahlan.

Suhardjo. (2000). Pemberian Makanan Pada Bayi dan Anak. Yogyakarta: Kanisius.

Wirdayanti, R. (2019). Pemberian Makan Bayi \& Anak. Yogyakarta: Cv. Budi Utama. 